\title{
Refractory myelodysplastic anaemias with hypocellular bone marrow
}

\author{
Y YOSHIDA, * S OGUMA, * H UCHINO, * T MAEKAWA $\dagger$ \\ From * the First Division, Department of Medicine, Kyoto University, Kyoto and $\dagger$ the Third Division, \\ Department of Medicine, Gunma University, Maebashi, Japan
}

SUMMARY Thirty three patients with refractory myelodysplastic anaemias (RMDA) with marrow hypocellularity were reviewed to see whether they differed from those with normocellular or hypercellular marrows.

The median age was 65 years with a male:female ratio of 26:7. There were 11 cases of refractory anaemia (RA), four of refractory anaemia with ringed sideroblasts (RARS), and 18 of refractory anaemia with excess of blasts (RAEB). All presented with peripheral cytopenias, mostly pancytopenia or bicytopenia, dysplasia in one or more cell lineages, and a marrow biopsy specimen with less than normal numbers of nucleated cells for the age. Twenty four patients died, including 14 of the 16 who developed acute non-lymphocytic leukaemia (ANLL).

The results suggest that patients with hypocellular RMDA have a similar prognosis to those with normocellular or hypercellular marrows at presentation.

Since the term myelodysplastic syndromes (MDS) was coined, several studies have reported on the clinicopathological, biological, and prognostic aspects, ${ }^{1-6}$ but whether patients with marrow hypocellularity should be excluded has been a matter for controversy. Most authors have restricted the term MDS to those with normocellular to hypercellular marrow ${ }^{27-9}$; though others, ${ }^{10-14}$ on the basis of bone marrow biopsy findings, have included patients with varying degrees of marrow hypocellularity as well. This second option has not been fully accepted by most haematologists.

This paper describes the clinical and pathological features of patients with hypocellular refractory myelodysplastic anaemias (RMDA) and compares their natural history with that of normocellular to hypocellular cases. The term RMDA is retained here to encompass the three major subtypes of MDS; refractory anaemia (RA), refractory anaemia with ringed sideroblasts (RARS), and refractory anaemia with excess of blasts (RAEB).

\section{Material and methods}

Data from 33 cases (26 men, seven women) of RMDA with marrow hypocellularity were reviewed. The median age was 65 years, range $26-92$ years. They represented $7.7 \%$ of a total of 428 cases of RMDA registered by the Japanese Cooperative Study Group

Accepted for publication 18 February 1988 up to April 1987. Follow up ranged from five to 152 months. All fulfilled the diagnostic criteria set out by the group. ${ }^{1516}$ RAEB and evolution to ANLL were diagnosed according to the FAB classification. ${ }^{2}$ RARS was defined as ringed sideroblasts comprising more than $20 \%$ of marrow erythroblasts. ${ }^{15}$ Cases not meeting the criteria for RAEB or RARS, yet showing cellular dysplasias or normocellular to hypocellular marrow, or a combination, were defined as RA. ${ }^{15}$ Excluded were those with myeloproliferative disorders, aplastic anaemias, deficiencies, or a history of exposure to myelotoxic agents. ${ }^{15} 16$

When the marrow aspirates showed a normal to increased cellularity in smears a cellular marrow was diagnosed, but in cases with a decreased cellularity in smears, the marrow cellularity was evaluated in sections of iliac crest biopsy specimens obtained with the Jamshidi needle. ${ }^{17}$ Hypocellularity was defined in biopsy sections relative to the normal range of iliac marrow cellularity in a given age group. ${ }^{18}$ The bone marrow biopsy specimen was therefore considered to be hypocellular when less than $30 \%$ of the marrow consisted of haemopoietic cells in patients below 60 years and less than $20 \%$ in patients older than 60 years. Although this is arbitrary and there is a considerable variation in the distribution of fat and haemopoietic cells, ${ }^{18}$ this definition of marrow hypocellularity is comparable with that of most other investigators. ${ }^{19-21}$

Dysplasias of blood and marrow cells were recorded 
Table 1 Clinical and haematological data of patients with RA and RARS showing hypocellular marrow

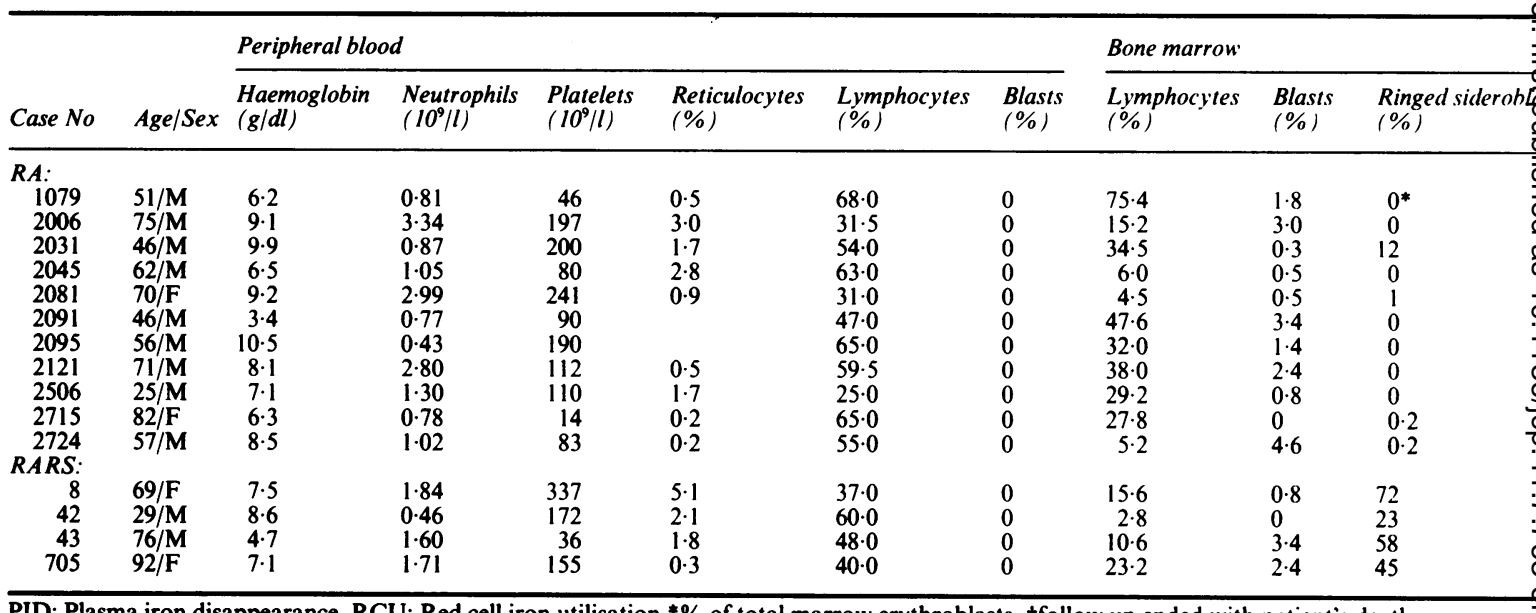

PID: Plasma iron disappearance, RCU: Red cell iron utilisation, $* \%$ of total marrow erythroblasts, + follow up ended with patient ${ }^{\circ}$ death.

as none $(-)$, moderate $(+)$, and pronounced $(++)$, based on the prevalence and degree of the abnormality within each cell lineage. ${ }^{15}$ Briefly, 500 cell myelograms were performed. Dyserythropoiesis and dysgranulopoiesis was defined as $(+)$ or $(++)$ if one or more than two of the following morphological changes were present in each cell lineage. There were megaloblastoid changes, other nuclear anomalies such as multinuclearity, and ringed sideroblasts in the erythroid series; and nuclear and granular abnormalities in the granulocytic series. At least 20 megakaryocytes were examined separately for the presence of micromegakaryocytes and megakaryocytes with small round nuclei, in addition to giant platelets in the blood film.
Other variables analysed included serial blood and marrow differential counts, percentage of ringed sideroblasts, and ferrokinetic, cytogenetic, and marrow cell culture data. Statistical analysis of the prognostic variables was performed as described elsewhere. $^{15}$

\section{Results}

\section{HY POCELLULAR RA AND RARS}

Table 1 details the clinical and haematological data of 15 patients with hypocellular RA and RARS. All were anaemic at the time of presentation. Eight had a platelet count of less than $150 \times 10^{9} / 1$ and 12 a

Table 2 Clinical and haematological data of patients with RAEB showing hypocellular marrow

\begin{tabular}{|c|c|c|c|c|c|c|c|c|c|}
\hline \multirow[b]{2}{*}{ Case No } & \multirow[b]{2}{*}{ Age/Sex } & \multicolumn{6}{|l|}{ Blood } & \multicolumn{2}{|l|}{ Marrow } \\
\hline & & $\begin{array}{l}\text { Haemoglobin } \\
(\mathrm{g} / \mathrm{dl})\end{array}$ & $\begin{array}{l}\text { Neutrophils } \\
\left(10^{9} / l\right)\end{array}$ & $\begin{array}{l}\text { Platelets } \\
\left(10^{9} / l\right)\end{array}$ & $\begin{array}{l}\text { Reticulocytes } \\
(\%)\end{array}$ & $\begin{array}{l}\text { Lymphocytes } \\
(\%)\end{array}$ & $\begin{array}{l}\text { Blasts } \\
(\%)\end{array}$ & $\begin{array}{l}\text { Lymphocytes } \\
(\%)\end{array}$ & $\begin{array}{l}\text { Blasts } \\
(\%)\end{array}$ \\
\hline $\begin{array}{l}1005 \\
1013 \\
1043 \\
1044 \\
1048 \\
1050 \\
1060 \\
1063 \\
1076 \\
1084 \\
1101 \\
1115 \\
1502 \\
1508 \\
1705 \\
1735 \\
1741 \\
1750\end{array}$ & $\begin{array}{l}71 / \mathrm{M} \\
71 / \mathrm{F} \\
83 / \mathrm{M} \\
73 / \mathrm{F} \\
76 / \mathrm{M} \\
54 / \mathrm{M} \\
61 / \mathrm{M} \\
73 / \mathrm{F} \\
60 / \mathrm{M} \\
40 / \mathrm{M} \\
65 / \mathrm{M} \\
57 / \mathrm{M} \\
61 / \mathrm{M} \\
52 / \mathrm{M} \\
77 / \mathrm{M} \\
62 / \mathrm{M} \\
66 / \mathrm{M} \\
65 / \mathrm{M}\end{array}$ & $\begin{array}{r}9.2 \\
8.8 \\
5.2 \\
7.2 \\
6.4 \\
12.5 \\
8.8 \\
11.1 \\
10.2 \\
5.9 \\
11.1 \\
11.2 \\
6.4 \\
7.3 \\
11.7 \\
5.4 \\
8.1 \\
6.6\end{array}$ & $\begin{array}{l}0.33 \\
0.10 \\
0.79 \\
0.82 \\
0.39 \\
0.05 \\
0.50 \\
0.57 \\
0.67 \\
1.25 \\
1.46 \\
0.66 \\
0.13 \\
0.84 \\
0.75 \\
0.30 \\
0.27 \\
0.41\end{array}$ & $\begin{array}{r}28 \\
66 \\
267 \\
40 \\
121 \\
64 \\
36 \\
100 \\
76 \\
147 \\
154 \\
68 \\
19 \\
30 \\
69 \\
77 \\
225 \\
128\end{array}$ & $\begin{array}{l}2.5 \\
1.0 \\
2.0 \\
1.2 \\
0.5 \\
0.1 \\
1.3 \\
0.9 \\
1.0 \\
0.5 \\
2.8 \\
\\
2.0 \\
0.1 \\
2.0 \\
0.4 \\
2.2 \\
0.1\end{array}$ & $\begin{array}{l}60.0 \\
82.0 \\
54.0 \\
40.0 \\
30.5 \\
94.0 \\
80.0 \\
70.0 \\
36.0 \\
41.0 \\
53.0 \\
61.0 \\
87.0 \\
63.0 \\
70.0 \\
67.0 \\
67.0 \\
68.0\end{array}$ & $\begin{array}{l}2 \cdot 0 \\
0 \\
2 \cdot 0 \\
3 \cdot 0 \\
0 \\
0 \\
0 \\
0 \\
0 \\
0 \\
0 \\
0 \\
0 \\
0 \\
0 \\
2 \cdot 0 \\
2 \cdot 0 \\
0\end{array}$ & $\begin{array}{r}20 \cdot 8 \\
17 \cdot 7 \\
16 \cdot 8 \\
16 \cdot 2 \\
42 \cdot 0 \\
64 \cdot 0 \\
22 \cdot 0 \\
34 \cdot 0 \\
4 \cdot 4 \\
52 \cdot 0 \\
31 \cdot 2 \\
19 \cdot 2 \\
20 \cdot 0 \\
32 \cdot 7 \\
28 \cdot 0 \\
36 \cdot 3 \\
8 \cdot 1 \\
29 \cdot 2\end{array}$ & $\begin{array}{r}14.8 \\
6.0 \\
16.8 \\
8.0 \\
12.8 \\
12.0 \\
18.0 \\
12.5 \\
13.0 \\
6.0 \\
14.0 \\
11.0 \\
19.1 \\
11.4 \\
16.0 \\
14.3 \\
9.9 \\
9.6\end{array}$ \\
\hline
\end{tabular}




\begin{tabular}{|c|c|c|c|c|c|c|c|c|}
\hline \multicolumn{2}{|c|}{ Ferrokinetics } & \multicolumn{3}{|l|}{ Dysplasia } & \multirow[b]{2}{*}{$\begin{array}{l}\text { Chromosome } \\
\text { anomaly }\end{array}$} & \multicolumn{3}{|c|}{ Outcome } \\
\hline $\begin{array}{l}\text { PID } \\
\text { (minutes) }\end{array}$ & $\begin{array}{l}R C U \\
(\%)\end{array}$ & Dyserythropoiesis & Dysgranulopoiesis & Dysmegakaryopoiesis & & $A N L L$ & $\begin{array}{l}\text { Survival } \\
\text { (months) }\end{array}$ & $\begin{array}{l}\text { Cause } \\
\text { of death }\end{array}$ \\
\hline \multicolumn{2}{|c|}{ ND } & - & + & + & - & + & $30 \cdot 0 \dagger$ & \multirow[t]{2}{*}{ Infection } \\
\hline 116 & 69 & ++ & ++ & + & - & - & 20.7 & \\
\hline 125 & 57 & + & - & - & ND & - & $40 \cdot 1 \dagger$ & \multirow[t]{3}{*}{ Bleeding } \\
\hline 280 & 52 & - & - & + & ND & - & $20 \cdot 0$ & \\
\hline 165 & 77 & ++ & - & - & ND & - & $15 \cdot 8$ & \\
\hline NI & & ++ & ++ & + & - & + & $8.6+$ & \multirow{6}{*}{$\begin{array}{l}\text { Infection } \\
\text { Unknown } \\
\text { Unrelated death }\end{array}$} \\
\hline $\mathrm{NI}$ & & + & ++ & + & - & - & $24 \cdot 0 \dagger$ & \\
\hline 105 & 5 & - & + & ++ & + & + & $11.0 \dagger$ & \\
\hline \multirow{3}{*}{ ND } & 83 & - & - & + & ND & - & 113.0 & \\
\hline & & ++ & - & - & ND & - & $44 \cdot 0$ & \\
\hline & 9 & ++ & ++ & + & + & - & $12 \cdot 0$ & \\
\hline $36 \cdot 5$ & 18 & + & - & - & - & - & $14 \cdot 0+$ & Unrelated death \\
\hline 252 & 40 & + & + & ++ & + & - & 61.0 & \\
\hline $\begin{array}{l}153 \\
54\end{array}$ & $\begin{array}{l}40 \\
63\end{array}$ & + & + & ++ & + & - & $38 \cdot 0 \dagger$ & Infection \\
\hline 54 & 63 & ++ & - & - & - & - & $24 \cdot 0 \dagger$ & Unrelated death \\
\hline
\end{tabular}

neutrophil count of less than $2 \times 10^{9} / 1$. The median lymphocyte count in the blood was $54.0 \%$ with a range of $25-68 \%$ while that in the marrow was $23.2 \%$ with a range of $2 \cdot 8-75 \cdot 4 \%$. Eight showed dysplasia in more than two cell lineages. Dysplasia was confined to single cell lineage in seven, notably erythroid in five, and megakaryocytic in two patients. Ferrokinetic data were available in 11 patients. Only two patients showed an aplastic pattern - that is, prolonged plasma iron disappearance and decreased red cell utilisation of radioiron. Some patients also showed a near normal growth of haemopoietic colonies in marrow cell cultures despite marrow hypocellularity (data not shown). Four of the five in whom dysplasia was confined to erythroid lineage showed a normal to shortened plasma iron disappearance, a decreased red cell utilisation, and a nearly normal platelet count. Eight patients died, including three who developed ANLL.

\section{HYPOCELLULAR RAEB}

All 18 patients presented with varying degrees of pancytopenia except for two with normal platelet counts (table 2). All had a relative lymphocytosis in the blood. The median marrow lymphocyte was $25 \%$ with a range of $4 \cdot 4-64.0 \%$. The marrow blast cell was $6-$ $19 \cdot 1 \%$. Tricellular lineage dysplasia was found in six patients. Dysplasia in two cell lineages was found in seven patients, while single cell lineage dysplasia was found in five-that is, three myeloid and two erythroid. Sixteen patients died, including 11 of the 13 who developed ANLL. The main causes of death were

\begin{tabular}{|c|c|c|c|c|c|c|c|c|}
\hline \multicolumn{2}{|c|}{ Ferrokinetics } & \multicolumn{3}{|l|}{ Dysplasia } & \multirow[b]{2}{*}{$\begin{array}{l}\text { Chromosome } \\
\text { anomaly }\end{array}$} & \multicolumn{3}{|c|}{ Outcome } \\
\hline $\begin{array}{l}\text { PID } \\
\text { (minutes) }\end{array}$ & $\begin{array}{l}R C U \\
(\%)\end{array}$ & Dyserythropoiesis & Dysgranulopoiesis & Dysmegakaryopoiesis & & $A N L L$ & $\begin{array}{l}\text { Survival } \\
\text { (months) }\end{array}$ & $\begin{array}{l}\text { Cause } \\
\text { of death }\end{array}$ \\
\hline \multirow{5}{*}{$\begin{array}{r}180 \\
67\end{array}$} & 70 & - & + & - & - & + & $14.0 \dagger$ & \multirow{8}{*}{$\begin{array}{l}\text { Infection } \\
\text { Infection } \\
\text { Renal failure } \\
\text { Infection } \\
\text { Infection } \\
\text { Infection } \\
\text { Infection }\end{array}$} \\
\hline & 23 & - & + & - & - & - & $7.4 \dagger$ & \\
\hline & & - & + & + & + & - & $5.0+$ & \\
\hline & & + & + & + & - & + & $24.0 \dagger$ & \\
\hline & & + & ++ & - & ND & - & $14.4 \dagger$ & \\
\hline \multirow[t]{2}{*}{200} & \multirow[t]{2}{*}{$5 \cdot 2$} & + & + & ++ & - & + & $6 \cdot 7 \dagger$ & \\
\hline & & + & + & - & ND & + & $7 \cdot 2 \dagger$ & \\
\hline \multirow{5}{*}{$\begin{array}{l}155 \\
175\end{array}$} & $\begin{array}{l}95 \\
46 \cdot 2\end{array}$ & $\stackrel{+}{+}$ & + & ++ & ND & + & 67.0 & \\
\hline & & $\stackrel{+}{+}+$ & $\begin{array}{l}+ \\
+\end{array}$ & $\begin{array}{l}+ \\
+\end{array}$ & $\stackrel{+}{-}$ & $\begin{array}{l}+ \\
+\end{array}$ & $\begin{array}{l}4 \cdot 7 \dagger \\
5 \cdot 4 t\end{array}$ & \multirow{3}{*}{$\begin{array}{l}\text { Bleeding } \\
\text { Infection } \\
\text { Bleeding }\end{array}$} \\
\hline & & - & + & ++ & - & $\begin{array}{l}+ \\
+\end{array}$ & $\begin{array}{l}3.4 \mathrm{~T} \\
3.0+\end{array}$ & \\
\hline & & ++ & + & ++ & ND & + & 22.7 & \\
\hline & & + & + & - & - & - & $20 \cdot 0 \dagger$ & Infection \\
\hline \multirow{4}{*}{33} & 15 & + & + & - & + & + & $1.4 \dagger$ & Infection \\
\hline & & $\stackrel{+}{+}+$ & $\bar{t}$ & - & ND & + & $18 \cdot 0 \dagger$ & Bleeding \\
\hline & & $\begin{array}{l}++ \\
+\end{array}$ & $\stackrel{+}{-}$ & - & $\underline{\text { ND }}$ & $\bar{t}$ & $18 \cdot 7 \dagger$ & Infection \\
\hline & & - & + & - & $\overline{N D}$ & $\begin{array}{l}+ \\
+\end{array}$ & $\begin{array}{r}7.7 \dagger \\
13.3 \dagger\end{array}$ & $\begin{array}{l}\text { Infection } \\
\text { Infection }\end{array}$ \\
\hline
\end{tabular}


infections in 13, and bleedings in three. The patients with hypocellular RAEB tended to have a higher incidence of evolution to ANLL than those with normocellular to hypercellular marrow (data not shown). There was no significant difference in the leukaemia free survival between the two groups $\left(\chi^{2}=\right.$ 3.123, Mantel-Cox test, 0.1 $>p>0.05$ ). Similarly, these two groups did not differ significantly in survivals $\left(\chi^{2}=2.57, p>0.1\right)$ or in the rate of nonleukaemic death $\left(\chi^{2}=0.681, \mathrm{NS}\right)$.

\section{Discussion}

This study shows the presence of marrow hypocellularity confirmed by biopsy in a small proportion $(7.7 \%)$ of patients with RMDA. Hypocellular RMDA was distinct from aplastic anaemia in cellular dysplasia, cytogenetic and ferrokinetic findings, and a high rate of evolution to ANLL (tables 1 and 2). Hypocellular RAEB also differed from hypoplastic leukaemia in the percentage of marrow blasts. The percentage of marrow blasts is usually greater than $30 \%$ in hypoplastic leukaemia, ${ }^{19}$ although some overlapping cases have been reported..$^{22}$

A somewhat higher incidence of hypocellular MDS has been reported where marrow histology has been assessed by trephine biopsy. ${ }^{11323}$ As not all cases showing cellular marrow in aspirates were studied by trephine biopsy, the proportion of observed hypocellular RMDA may be an underestimate of the true percentage of hypocellularity. Estimation of marrow cellularity usually shows a good correlation between smears of aspirates and biopsy specimens but this correlation may be lost in MDS, probably due to pronounced topographic variation. Variability of cellularity ${ }^{112}$ and irregular distribution of haemopoietic cells ${ }^{132324}$ seem to be histological characteristics of MDS. Such topographic variability may explain the discrepancy occasionally seen in this study between marrow cellularity and ferrokinetic findings (tables 1 and 2). In addition, ferrokinetic findings are a measure of the erythropoietic activity of the whole body and do not necessarily correspond to the marrow cellularity of a single marrow site, to which many nonerythroid cells may contribute. As aspirations and biopsies are mutually complementary, both procedures, preferably from different sites, are required to evaluate marrow cellularity reliably.

Several factors may account for marrow hypocellularity in RMDA which usually shows cellular marrow. First, hypocellular myelodysplasia may precede hypercellular myelodysplasia. ${ }^{14}$ Although in the present series repeat biopsy specimens were not taken in every case, this possibility is unlikely as some remained hypocellular throughout follow up and hypocellularity was found to the same degree in all three subtypes of RMDA.

Secondly, hypocellular RMDA may represent a distinct clinicopathological entity. Hypocellular marrow with increased blasts has been characterised by an association with exposure to myelotoxic agents, severe marrow failure, and a poor response to chemotherapy. ${ }^{21}$ Marrow hypocellularity and fibrosis have been seen in secondary or mutagen-related MDS/ ANLL ${ }^{1-3}$ though in our study no patients with a known history of myelotoxic exposure were included. A recent report suggested that among MDS patients those with hypocellular marrow developed leukaemia less often, responded to androgens more often, and survived longer than those with cellular marrow. ${ }^{25} \mathrm{We}$ have found no evidence to support this. Our patients showed no significant difference in overall survival, leukaemia free survival, or death from other causes among those with hypocellular or cellular RMDA. In fact, patients with hypocellular RAEB tended to be at even higher risk of developing ANLL than those with cellular RAEB. The exact nature of the hypocellular RMDA or the suggestion that damage to the marrow may manifest itself in several ways ${ }^{26}$ remains to be investigated further.

Hypocellularity in single marrow aspirates does not preclude the diagnosis of RMDA. Trephine bone marrow biopsy specimens obtained from different sites are needed to make the diagnosis. ${ }^{27}$ The fact that hypocellular RMDA does exist should be borne in mind when planning the treatment of these enigmatic disorders.

This work was partly supported by Grants in Aid for Scientific Research (61480258, 62570542) from the Ministry of Education, and Grants for Intractable Diseases from the Ministry of Health and Welfare of Japan. We thank Miss Y Kitagawa for preparing the manuscript.

\section{References}

1 Greenberg PL. Biologic abnormalities in the myelodysplastic syndromes and myeloproliferative disorders. Acta Haematol Jpn 1986;49:1509-27.

2 Bennet JM, Catovsky D, Daniel MT, et al. Proposals for the classification of the myelodysplastic syndromes. $\mathrm{Br} \mathrm{J}$ Haematol 1982;51:189-99.

3 Galton DAG. The myelodysplastic syndromes. Clin Lab Haematol 1984;6:99-112.

4 Koeffier HP. Myelodysplastic syndromes (preleukemia). Semin Hematol 1986;23:284-99.

5 Jacobs A. Myelodysplastic syndromes: pathogenesis, functional abnormalities, and clinical implications. J Clin Pathol 1985;38:1201-17.

6 Yoshida Y. Biology of the myelodysplastic syndromes. Int J Cell Cloning 1987;5:356-75.

7 Vallespi T, Torrabadella M, Julia A, et al. Myelodysplastic syndromes. A study of 101 cases according to the FAB classification. Br J Haematol 1985;61:83-92.

8 Varela BL, Chuang C, Woll JE, Bennett JM. Modifications in the 
classification of primary myelodysplastic syndromes. The addition of a scoring system. Haematol Oncol 1985;3:55-63.

9 May SJ, Smith SA, Jacobs A, et al. The myelodysplastic syndrome: analysis of laboratory characteristics in relation to the FAB classification. Br J Haematol 1985;59:311-19.

10 Najean Y, Pecking A. Refractory anaemia with excess of myeloblasts in the bone marrow: a clinical trial of androgens in 90 patients. Br J Haematol 1977;37:25-33.

11 Coiffier B, Adeleine P, Viala JJ, et al. Dysmyelopoietic syndromes. A search for prognostic factors in 193 patients. Cancer 1983;52:83-90.

12 Rosenthal DS, Moloney WC. Refractory dysmyelopoietic anemia and acute leukemia. Blood 1984;63:314-18.

13 Tricot G, De Wolf-Peeters C, Hendrickx B, Verwilghen RL. Bone marrow histology in myelodysplastic syndromes. I. Histological findings in myelodysplastic syndromes and comparison with bone marrow smears. Br J Haematol 1984;57:423-30.

14 Fohlmeister I, Fischer R, Schaefer HE. Preleukemic myelodysplastic syndromes (MDS): pathogenetical considerations based on retrospective clinicomorphological sequential studies. Anticancer Res 1985;5:179-88.

15 Yoshida Y, Oguma S, Uchino H, Maekawa T. Clinical features and prognosis of refractory myelodysplastic anemias: a Japanese Cooperative Study. Acta Haematol Jpn 1987;50:37-45.

16 Oguma S, Yoshida Y, Uchino H, Maekawa T. Factors influencing leukemic transformation in refractory anemias with excess of blasts, with ringed sideroblasts and without ringed sideroblasts. Cancer Res 1986;46:3698-700.

17 Fong TP, Okafor LA, Schmitz TH, et al. An evaluation of cellularity in various types of bone marrow specimens. Am J Clin Pathol 1979;72:812-16.
18 Hartsock RJ, Smith EB, Petty CS. Normal variations with aging of the amount of hematopoietic tissue in bone marrow from the anterior iliac crest. Am J Clin Pathol 1965;43:326-31.

19 Needleman SW, Burns CP, Dick FR, Armitage JO. Hypoplastic acute leukemia. Cancer 1981;48:1410-14.

20 Howe RB, Bloomfield CA, McKenna RW. Hypocellular acute leukemia. Am J Med 1982;72:391-5.

21 Gladson CL, Naeim F. Hypocellular bone marrow with increased blasts. Am J Hematol 1986;21:15-22.

22 Beard MEJ, Bateman CJT, Crowther DC, et al. Hypoplastic acute myelogenous leukaemia. $\mathrm{Br}$ J Haematol 1975;31:167-76.

23 Frisch B, Bartl R. Bone marrow histology in myelodysplastic syndromes. Scand J Haematol 1986;36(Suppl 45):21-37.

24 Fohlmeister I, Fischer R, Mödder B, Rister M, Schaefer HE. Aplastic anaemia and the hypocellular myelodysplastic syndrome. Histomorphological, diagnostic, and prognostic features. J Clin Pathol 1985;38:1218-24.

25 Riccardi A, Giordano M, Girino M, et al. Refractory cytopenias. Clinical course according to bone marrow cytology and cellularity. Blut 1987;54:153-63.

26 Mufti GJ, Hamblin TJ, Lee-Potter JP. The aplasia-leukaemia syndrome. Aplastic anaemia followed by dyserythropoiesis, myeloproliferative syndrome and acute myeloid leukaemia. Acta Haematol 1983;69:349-52.

27 Appelbaum FR, Barrall J, Storb R, et al. Clonal cytogenetic abnormalities in patients with otherwise typical aplastic anemia. Exp Hematol 1987;15:1134-9.

Requests for reprints to: Dr Y Yoshida, Assistant Professor, The First Division, Department of Medicine, Kyoto University, 54 Shogoin-Kawaramachi, Sakyo, Kyoto 606, Japan. 